\title{
FILOSOFISK LIVSKUNST \\ Fra ledelse og terapi til aldring og de syv dødssynder
}

\section{Anders Draeby}


Filosofisk livskunst - fra ledelse og terapi til de syv dødssynder

København og Aarhus 2016

Copyright @ Anders Drœby

ISBN: 978-87-7507-373-3

DOI: 10.7146/aul.140.121

Afdeling for Generel pœdagogik og Pœdagogisk filosofi

Danmarks Institut for Pœdagogik og Uddannelse

AARHUS UNIVERSITET

/ 


\section{Indhold}

Indledning

1. Pierre Hadot og Michel Foucault om filosofisk livskunst

4

2. Ledelse og filosofisk livskunst

9

3. De døde synders klub - et samtidsdiagnostisk essay om dødssynder i den moderne kultur

4. Om at have forspildt sit liv

5. Om at leve en dag ad gangen

6. Om døden

7. Kunsten at blive gammel: Gerontopœdagogisk livskunst

8. Om at vœre alene, ensom, isoleret eller forladt

9. En filosofisk udvikling af grundlaget for en livsduelighedens terapi. 29 Revitalisering af eksistensfilosofien og stoicismen i terapeutisk henseende

10. Udfrielse fra lidelse - Et studie af livsduelighed som mål for en filosofisk terapeutik 


\section{Indledning}

De senere år er der kommet fornyet fokus på den filosofiske livskunst. Denne bog prcesenterer en rckke perspektiver på filosofisk livskunst og en rœkke ansatser til at genoplive og forny tilgangen. Teksterne er udarbejdet i perioden mellem 2011 og 2016.

Bogen kommer omkring Pierre Hadots og Michel Foucaults tilgange til filosofisk som livsform og livskunst, ledelse som filosofisk livskunst, de syv dødssynder i et aktuelt perspektiv, gerontopœedagogisk livskunst, filosofisk livskunst som terapi med et mål om livsduelighed, det forspildte liv og døden. 


\section{Pierre Hadot og Michel Foucault om filosofisk livskunst}

Hvad er overhovedet filosofisk livskunst?

I Europa bliver den filosofiske livskunst grundlagt som tradition i perioden mellem det femte og tredje århundrede før vor tidsregning.

Som den amerikanske filosof Martha Nussbaum påpeger, er den del af udgangspunktet for den filosofiske livskunst en forståelse af, at menneskelivet er fundamentalt skrøbeligt. Vi er udsat for alle mulige farer og risici, og derfor er det nødvendigt at udvikle en tilgang til livet, der gør os bedre i stand til at håndtere udfordringer.

Efter Alexander den Stores grundlœggelse af sit multikulturelle rige og med den efterfølgende grundløggelse af Romerriget nogle århundreder senere, bliver mennesket desuden konfronteret med en ny udfordring. Nemlig fremmedgørelse og rodløshed i et massesamfund.

Den stigende popularisering af den filosofiske livskunst skyldes iscer de to franske filosoffer Pierre Hadot og Michel Foucault

\section{Pierre Hadot om filosofien som livsform}

Pierre Hadot vender sig først og fremmest imod den moderne akademiske fagfilosofi. Ifølge Hadot er filosofien i dag blevet kunstig og beskceftiger sig med at udarbejde abstrakte og virkelighedsfjerne teorier. Samtidig er den moderne akademiske fagfilosofi først og fremmest blevet en tekstdisciplin, og den ser teksten som det primcere og teorien som et mål i sig selv.

Hos Pierre Hadot finder vi en derfor en forestilling om at genoplive filosofien som en praktisk livsform. Det vil sige, at filosofien oprindeligt var en praktisk livsindstilling og en praktisk livsstil. Her opnår vi autenticitet og eudaimonia gennem en bestemt trcening til døden og ved at leve efter et visdomsideal. 
I antikken var filosofien altså først og fremmest en livsform, og at vœre filosof betød, at man levede et filosofisk liv. Det var med andre ord ikke nødvendigt at have udarbejdet en teori eller at have taget en filosofisk universitetsuddannelse. Det vigtige var måden, man levede sit liv på.

I antikken er filosofien først og fremmest koncentreret om mundtlig overlevering. Filosofien skal vœre levende, og teksten er kun sekundœr. Teorien er altid underordnet praksis, og fokus er hverdagslivet.

Målet er at opnå sindsro og det sker ved at fjerne fordomme og forforståelser.

Filosofiens opgave er i den forbindelse at sørge for en spirituel transformation af selvet og livet. Det sker iscer gennem meditative og spirituelle øvelser, hvor vi gør brug af fornuften (logos). Ambitionen er at gøre os i stand til at forene os med verden.

Målet er altså at opnå eudaimonia, menneskelig blomstring, og derfor er filosofien også en scerlig slags terapi. Det handler nemlig om at helbrede os for de bekymringer og lidelser, som vi får på grund af vores begœr og overdrevne lidenskaber (passio).

Filosofien er med andre ord en bestemt livsindstilling og livsstil, der involverer hele eksistensen. Ambitionen er at hœve individet fra en inautentisk til en autentisk livsform. Det indebcrer at skabe øget bevidsthed og selvbevidsthed med en vision for verden og en indre fred og frihed.

Filosofien er i bund og grund en søgen efter visdom. I modsctning til vismanden har filosoffen netop ikke visdommen men kan kun søge efter den. Filosoffen kan aldrig opnå visdommen men er en ven af visdommen og lever efter et visdomsideal.

Filosofien er baseret på praktiske øvelser, der skal sikre spirituel eller åndelig udvikling mod visdomsidealet. Målet er som sagt en transformation af selv og liv. Det foregår altså gennem en meditativ udøvelse af fornuften der er analog til løgekunstens kur eller (iii) atletens trcening. Her er der fokus på selvkontrol.

I bogen What is Ancient Philosophy skelner Hadot mellem filosofi som diskurs og filosofi som en livsform. Det vil altså på den ene side sige tale og teorier om filosofi og på den anden side filosofien som en praktisk livsform. Vi finder filosofien som diskurs i bøger og artikler om filosofi og i undervisning om filosofi. Det vigtige er imidlertid filosofien som praktisk livsform. Ofte skal man undervises i filosofi, før man kan praktisere filosofi i sit liv. 
Filosofien er i den forbindelse ikke primœrt abstrakt teori, en rœkke teoretiske antagelser om verden eller en abstrakt-teoretisk aktivitet. Filosofien er i stedet en diskurs, der handler om at trcne folk til at leve og se på verden på en bestemt måde, altså til at leve et filosofisk liv.

Filosofien er ikke mindst en trœning til døden. Den filosofiske livsform handler altså om at løere at dø. Derfor udgør den en slags meditationer over døden.

Filosofien udøves inden for forskellige filosofiske skoler. Det vil sige stoicismen, kynismen, epikurœismen og skepticismen mv. De forskellige skoler er defineret ved forskellige visdomsidealer. At tilhøre en skole vil sige at man lever i overensstemmelse med skolens grundløgggende dogmer og livsregler. I den forbindelse reprcsenterer de forskellige skoler forskellige indre livsholdninger i det praktiske liv.

\section{Michel Foucault om selvomsorgens livskunst}

Den franske filosof og idéhistoriker Michel Foucault lader sig fra slutningen af 1970'erne og ind i 1980'erne inspirere af Pierre Hadots arbejde.

Hos Foucault finder vi en indsigt i, at filosofien fra og med René Descartes bliver fokuseret på viden og erkendelse om mennesket og dets selv. Foucault mener, at dette en modscetning til den tidligere filosofi, hvor erkendelse og viden - og herunder erkendelse og viden om selvet - var underordnet en omsorg for selvet.

Mens Hadot primcrt fokuserer på den tidlige filosofi som en spirituel praksis, hvis mål er at forene mennesket med verden, fokuserer Foucault derfor på den tidlige livskunst som en selvpraksis. Det vil sige en sœrlig filosofisk praksis, der er rettet mod et mål om selvomsorg. I den forbindelse angiver Foucault 3 faser i den tidlige selvomsorgs historie:

7. Oldgrcesk antik: Vi finder her et fokus på, at kende sig selv, der er underordnet et mål om at drage omsorg for sig selv som sjœl eller rettere psûche. Denne selvomsorg tager form som den rette brug af nydelser og begœer. Samtidig er den en forudsctning for vores erotiske og politiske aktiviteter. I den grœske antik er denne selvomsorg desuden sncevert knyttet til paedagogikken, dvs. det unge menneskets forpligtelse, og paideia som en dannels af dydighed. 
2. Hellenistisk og romersk etik: I hellenismen og romertiden finder vi en filosofisk omsorg for selvet, der tager form som spirituel og terapeutisk praksis. Denne omsorg udfordrer det politiske og det konventionelle liv og kompenserer for pcedagogik og paideia. Dvs. at livskunsten er en erstatning for den dårlige pœdagogik.

3. Tidlig kristendom: I den tidlige kristendom bliver selvomsorgen vendt mod et mål om religiøs frelse efter livet. Denne frelse opnås gennem en forpligtelse på at kende sin sjœl og bekende sine synder. Tanken er at mennesket skal udviske sit ego. Ifølge Foucault indebœrer dette en selvafvisning i lydighed for pastoren. Denne selvafvisning sammenfattes gerne med ordene ego non sum, ego.

For Foucault er det vigtigste den anden fase. Nemlig den hellenistiske og romerske livskunst. Denne kan ifølge Foucault inspirere til at udvikle et modsvar til konkurrencestat og neoliberalisme. Dette modsvar skal vœre en frihedens etik, der kan tage form som en eksistentiel livœstetik. Der er 3 hovedprincipper for den hellenistiske og romerske livskunst:

1. For det første må den tage form som psykagogik eller terapi i stedet for pœdagogik.

2. For det andet må den forme sig som en trœning til døden. Eudaimonia opnås i sidste ende gennem en konfrontation med vores egen død. Derfor er den filosofiske livskunst også en dødskunst.

3. For det tredje må den filosofiske livskunst tage form som en selvransagelse og selvundersøgelse af ens egen sjœl.

\section{Referencer}

Foucault, Michel (2005) The Hermeneutics of the Subject: Lectures at the College de France 198 1-1982. US: Picador

Hadot, Pierre (1995). Philosophy as a Way of Life. Oxford: Blackwell

Hadot, Pierre (2004). What is Ancient Philosophy? London: Harvard University Press

Luther, Martin et al (ed) (1998). Technologies of the Self: A Seminar with Michel Foucault. US: EDS Publications Ltd. 
Nussbaum, Martha, (2001). The Fragility of Goodness: Luck and Ethics In Greek Tragedy And Philosophy. Cambridge: Cambridge University Press 


\section{Ledelse og filosofisk livskunst}

Hvordan skal man leve sit liv, for at det bliver et godt liv? I sin oprindelige betydning er etikken en livskunst, der fokuserer på kunsten at leve et godt menneskeliv ud fra et ideal om livsvisdom. Dvs. et liv med mening og tilfredshed, uden lidelse og bekymringer. Denne tankegang er bcrende for filosofien igennem Hellenismen og Romerriget, og den genfindes på forskellig vis i en scerlig tradition fra Sokrates, buddhismen og den tidlige kristendom, over Rencssancen, dele af den moderne eksistensfilosofi og frem til Pierre Hadot og Michel Foucault.

Allerede fra antikken bliver den filosofiske livskunst sncevert forbundet med spørgsmålet om, hvordan man kan lede andre på en god måde. Platon fremhœver i dialogen Alkibiades, hvordan målet med den filosofiske livskunst er at scette os i stand til at kunne drage omsorg for vores egen sjœl. Vi må altså opnå en erkendelse af os selv og vores plads i verden for at kunne danne vores moralske karakter ud fra dyderne visdom, retskaffenhed, mådehold og mod og på den baggrund udfolde det gode liv i samfundet. Først derigennem bliver vi i stand til at kunne lede andre. Ledelsen forudscetter med andre ord etikken. Således er det vores personlige udvikling af karaktertrœk, der udgør grundlaget for, at vi kan forene den rette handling med det moralsk ansvarlige i vores lederskab. Der er altså en meget snœver forbindelse imellem vores magt over os selv og vores magt over andre. Denne forbindelse er altafgørende at tage højde for i det omfang, at vi som ledere må kunne sœtte os ud over vœre styret af vores egne karakterbrister og egoistiske egeninteresser. Både for at vi kan opnå et godt liv som ledere, og for at vi kan vaere i stand til at tage hånd om medarbejdernes og helhedens interesser.

Vi genfinder den samme forbindelse mellem filosofisk livskunst og ledelse hos romerske stoikere som den politiske rådgiver Lucius Annaeus Seneca og kejser Marcus Aurelius. Her ser vi, at enhver leder må fokusere på at forandre sig selv for at kunne lede andre på en god og retfœrdig måde. Det vil sige, at vi helt grundlœggende må aflœre vores laster og egoistiske tilbøjeligheder. Det handler blandt andet om at aflœre vores afhcengighed af ydre ting som social status, anerkendelse og titler, der i sidste ende blot gør os bekymrede og fanget af vores egne begcr efter mere. I stedet må vi forandre os selv og blive retskafne, œrlige, modige og livskloge mennesker, der er i stand til at opnå egentlig livstilfredshed ved at gøre gavn for andre. Først derigennem bliver vi i stand til 
at vœre gode ledere, der med sindsro og indre styrke kan føre andre mod det fœlles bedste.

Den filosofiske livskunst fik en stor betydning for den sydafrikanske politiker Nelson Mandela, der lœse Marcus Aurelius i fœengslet på Robben Island. Før Mandela kom i fœngsel var han en revolutioncer politiker fuld af vrede og aggressivitet, der mente, at Apartheid-regimet måtte omstyres gennem vœbnet kamp. Mandelas løesning af Aurelius bidrog til, at han indså, at før han kunne forandre det sydafrikanske samfund til det bedre, måtte han allerførst forandre sig selv og blive et hœederligt og retfœrdigt menneske. Den forandring gav ham styrken til at kunne glemme de uretfœrdigheder, han havde oplevet, og i stedet indgå i konstruktive forhandlinger med det politiske styre. Mandela blev Sydafrikas første demokratisk valgte prœsident og var med til at skabe en omfattende forandring af landet.

Den filosofiske livskunst fik også stor betydning for den amerikanske admiral James Stockdale. I 1965 blev Stockdale skudt ned med sit fly over Vietnam og var i nordvietnamesisk fangeskab indtil 1973. Inden sin deltagelse i Vietnamkrigen havde Stockdale incrdigt løest den romerske stoiker Epiktet. Han fortalte senere, at det var Epiktets filosofiske livskunst, der havde hjulpet ham til at overleve de mange år $\mathrm{i}$ fangeskab. Efter sin frigivelse brugte Stockdale i resten af livet de stoiske livsprincipper til at finde styrke og støtte. Både i hans arbejde som admiral, leder af et militœrakademi, leder under Reaganadministrationen og som kandidat til embedet som viceprœsident. Stockdale var kendt som en kløgtig og retfœrdig leder med stort overblik.

\section{Referencer}

Aurelius, Marcus (2014). Meditations. London: Penguin

Mandela, Nelson (2011). Conversations with Myself. US: Pan

Platon (2009-2015). Samlede varker. København: Gyldendal

Stockdale, James (1993). Courage under Fire: Testing Epictetus's Doctrines in a Laboratory of Human Behavior. US: Hoover Institution Press

Stockdale, James (1995). Thoughts of a Philosphical Fighter Pilot. EDS Publications Ltd. (Consignment) 


\section{De døde synders klub - et samtidsdiagnostisk essay om dødsynder i den moderne kultur}

De syv dødssynder er på vej til at blive almindeligt accepterede tilbøjeligheder. Den udvikling truer samfundets sammenhcengskraft.

Syndighed er sjovt og sexet. Dydighed er gammeldags og kedeligt. Budskabet skinner igennem i Enchanticals parfumekollektion, der har fået navn efter de syv dødssynder. Frigjorte kvinder er nemlig uartige og holder sig ikke tilbage. Den samme besked finder vi i nyere erhvervslitteratur. Her optrœeder de syv dødssynder som redskaber til at opnå lykke, succes og økonomisk frihed. Det er lige prœcist en "sinner", som gør forskellen på en taber og en vinder.

Hvorfor skal vi ikke bare gør os helt fri af forhistoriens forbud og skam og slå os løs?

Vores problem er måske, at vi opfatter de syv dødssynder som religiøse dogmer fra fortiden og ikke som vardifulde livsindsigter. For hvad er de syv dødssynder egentlig? Fra middelalderen bliver de syv dødssynder brugt som en etisk rettesnor. Hovmod, grådighed, frådseri, lystighed, misundelse, vrede og dovenskab. Syv problematiske tilbøjeligheder, som mennesket må lœgge låg på for ikke at blive for selvcentreret. Når mennesket bliver sig selv for meget, ja så ødelœgger det nemlig både forholdet til sig selv, andre mennesker, naturen og Gud. Som mennesker bliver vi altså meget hurtigt vores egen og vores omgivelsers vœrste fjende. Tilvœrelsen og samfundet går $i$ opløsning. Netop derfor skal vi holde os selv i stramme tøjler. Sådan fortcller en œldgammel livsvisdom, som de kristne overtager og gør til deres egen.

Men hvordan er forhold til dødssynderne så ved at œndre karakter, når tendensen sœttes på spidsen?

\section{Hovmod:}

Nutidens ungdom bliver kaldt mig-mig-mig-generationen. De er narcissistiske, selvovervurderende og krœvende. De unge er dog kun et spejl af kulturens udvikling. 
Individualisme, neoliberalisme og konkurrencestat understøtter en generel selvcentrering. Med en udbredt tendens til selvhœevdelse. I dag tager vi først og fremmest ansvar for os selv, og vi forsøger at opnå mest muligt for os selv. På en måde, der helst er synlig for andre og kan give status i den sociale konkurrence. Vi lever nemlig $i$ et samfund, der honorerer den ydre performans. Vi vurderer os selv og hinanden på udseende, prcstationer, magt, velstand og kompetencer. Vi jagter social anerkendelse og opfatter hver isœr os selv som potentielle verdensmestre, der gemmer på uanede talenter. Andre mennesker bliver i stigende grad vores konkurrenter. Vores omgang med dem praeges derfor af vores egen stolthed, arrogance og mistillid. Resultatet er, at vi let tilsidesœtter vores dybere behov for gensidigt fœllesskab og uselvisk kœrlighed.

\section{Grådighed:}

Finanskrisen afslørede, at finanssektorens grådighed er grcenseløs og kan bringe samfundet ud af balance. Finanssektoren er dog også bare et spejl af kulturens udvikling. Vœkstideologien har ophøjet grådigheden til et samfundsideal. Efterstrcebelsen af velstand, succes og status er blevet en dominerende vardi i det kapitalistiske samfund. Her er vi først og fremmest karrieremagere og menneskelige ressourcer på et reguleret marked.

Når kapitalismen overhovedet kan hœenge sammen, ja så skyldes det ikke mindst, at vi hver iscer har overtaget vakstideologien. Som en etisk rettesnor for vores eget liv, der gør os til slaver af et grœnseløst behov for nyt, mere og bedre. Selv vœkstkritikken bunder langt hen ad vejen i en forestilling om, at et snœvert fokus på økonomisk vœkst står i vejen for vores mere omfattende udvikling. Hele livet er blevet en ressource. Vi bestrcber os konstant på at optimere vores kroppe efter sundhedsidealer, vores udseende efter skønhedsidealer og vores selv efter perfektionsidealer. I dag omfatter vores karriere ikke alene vores uddannelse og arbejde. Den omfatter hele livet, og vi søger konstant nye udfordringer som tegn på, at vi er i udvikling og ikke under afvikling. Men det er kun en cancercelle, der vokser for vakstens skyld. Resultatet er ikke alene en risiko for udmattelse, som viser sig i tidens tendenser til depression og stress. Resultatet er også en hverdag, der let bliver prœget af œngstelse og frygt. Fordi vi bekymres for ikke at få nok eller miste det, som vi allerede har fået. 


\section{Frådseri:}

Vores vakstbehov hcenger sncevert sammen med at vi lever i et kapitalistisk forbrugersamfund. Det gennemsyrer hele vores livsstil. Mange mennesker er ganske vist blevet mere bevidste om naturressourcer, dyrevelfœrd og bœredygtighed. I bund og grund handler denne bevidsthed dog om at sikre os ressourcer nok at forbruge $\mathrm{i}$ fremtiden. Og dermed garantere en holdbar vœkst. Vi har nemlig fået et forbrugsforhold til alt omkring os. Med et konstant ønske om nye livsstilsprodukter, større fladskœrme, modetøj og bedre boliger. Forbrugskritikerne adskiller sig kun fra luksusforbrugerne gennem deres måde at forbruge på. Fair trade eller first class.

I dag omfatter vores grœnseløse forbrugerisme selv forholdet til andre mennesker. I stedet for at vœre en del af et overordnet socialt fœllesskab har vi nu hver isœr et netvœrk. Det kan vi forbruge med henblik på at sikre vœksten i vores egen karrieretilvœrelse. Selv det at få børn bliver en del af vores individuelle projekt og er dermed også en investering $i$ et forbrugsgode. Som et resultat mister vi gradvist vardscttelsen af dén del af verden og de mennesker, som vi ikke kan forbruge til at optimere vores egen selvcentrerede dagsorden.

\section{Lystighed:}

Den omsiggribende seksualisering af det offentlige rum viser, at grådigheden og forbrugerismen også gclder vores begœr. Den seksuelle frigørelse har gjort vores lyster til et afgørende tegn på frihed. Vi skal også helst have et rigt og varieret sexliv for at blive lykkelige. Med Joan Ørting i spidsen er sexologerne dermed også blevet en ny tids prœsteskab, som prœdiker løs om frelsen ved at knalde løs. Det gœlder iscr for kvinder og homoseksuelle. Deres antageligt undertrykte og tabubelagte seksualitet skal helst udforskes i alle afkroge, omtales konstant og udstilles for alle og enhver. Samtidig er pornografiens massive og allestedsncervœrende udbredelse et udtryk for, at vi forherliger en instrumentel forbrugstilgang til vores lyster. Som nogle vi kan udleve, når det passer os selv uden at skulle indblande andre.

Den danske alkoholkultur demonstrerer vi tilsvarende vis, at vi også er blevet storforbrugere af en verdslig ekstase. Vi skal helst skal vœre påvirkede af stimulanser for 
at have det så sjovt som overhovedet muligt sammen med andre. Og dermed hverken mœrke os selv eller de andre. Vi er netop på vej til at blive selvcentrerede hedonister, som mere og mere søger den hurtige og kunstige selvtilfredsstillelse og derfor fortrœnger lidelse og alvor. Dermed formår vi heller ikke at lade seksualiteten og ekstasen vœre unikke oplevelser, der er svcere at opnå. Som netop fordrer en dyb intimitet med et andet menneske eller en højere magt. Resultatet af vores lystighed er jo netop, at vi både bliver fremmedgjorte over for alvoren og den krœvende intimitet. Og mister evnen til at drage omsorg for andre. Isœr for dem som er i krise og dermed ikke lige kan give os selv en sjov oplevelse.

\section{Misundelse:}

Jo mere selviske og grådige vi bliver i et forbrugersamfund, som forherliger konkurrence og begcer. Jo mere sammenligner vi os selv med andre og bliver ramt af misundelse. Begcret efter af få hvad de andre har. Fordi hele vores selvvœrd afhcenger af ydre vardier. Førhen sagde Janteloven, at jeg ikke skulle tro, at jeg var mere end andre. I dag siger Egoloven, at ingen må tro de er mere end mig. Eller have mere end mig. Nej, ingen må få noget, som jeg ikke får. De må da slet ikke snyde sig til det. Misundelsen er netop drivkraften i den rå kapitalisme, hvor vi er hinandens konkurrenter og skal kœmpe om at få mest muligt til os selv.

Velfœerdsstaten forsøgte at afbalancere kapitalismen med principper om ligelig fordeling, solidaritet i fœllesskab, demokrati og omsorg for alle og enhver. Konkurrencestaten søger derimod at mobilisere borgere og virksomheder til at deltage med hud og hår i den globale konkurrence og tilpasse sig. Uden at tage hensyn til andre principper. Vi opmuntres til at tage ansvar for vores eget liv i en alles kamp mod alle. Om at få de bedste karakterer, den bedste uddannelse, det bedste job, den bedste indtœgt, den bedste partner, det smarteste tøj og den bedste bolig. Alt i livet og samfundet skal hele tiden måles og vejes, så det kan økonomiseres og sammenlignes indbyrdes.

Idet økonomien dermed bliver ophøjet til ideologi, fjendskabet bliver det sociale bånd, og misundelsen bliver en uudtalt œrkedyd. Ja så tilsidesctter vi ikke alene evnen til at 
glœdes på andres vegne. Vi bliver mere vagtsomme og taber tilliden til hinanden. Vi mister den sociale accept og får svcerere ved at acceptere omfordeling til dem, som ikke har noget og har svœert ved at klare sig i konkurrencen. De nasser bare på os andre. Generøsiteten forsvinder.

Samtidig efterligner vi hinanden mere og mere og tilpasser os en ensrettet livsforestilling. Konforme individualister. Med det resultat, at vi fortrcenger de originale og unyttige sider af os selv og taber evnen til at vœrdsctte hinandens forskelligheder.

\section{Vrede:}

Med vores selviskhed og grådighed følger også en forøget vrede. Mod alle dem som truer vores ego i kampen for at holde på vores og opnå en social position, velstand, forbrugsgoder og seksuelle oplevelser. I det omfang vi går fra at vœre en del af et overordnet socialt fœllesskab til at have et selvvalgt socialt netvœrk. Ja så bliver fjendskabet også et vœsentligt pejlemœrke for vores tilvœrelse. Mine venner bliver dem, som kan bidrage nyttigt til min karrieretilvœrelse, mens mine personlige fjender lige pludselig bliver alle dem, som truer livsprojektet på den ene eller den anden måde. Fordi de ikke vil anerkende mig, fordi jeg er misundelig på dem, fordi de ikke vil knalde eller drikke sig fulde med mig, eller fordi de vinder over mig. Jo mere alle andre bliver mine konkurrenter. Jo mere udviskes grœnsen mellem ven og fjende imidlertid også, og vi bliver alle sammen kyniske aktører i et kompliceret virkelighedsspil. Hvor vi hele tiden indgår og bryder alliancer med henblik på at vinde.

I konkurrencestaten bliver hovedfjenden dog dem, som udgør en trussel imod selve konkurrencen. Alle dem som ikke vil tage ansvar for deres eget liv og komme ind i den store kamp. Hvor vi sammenligner os med hinanden og efterligner. Vurderer og tilpasser os. Det bliver stadig mere legitimt at tale åbenlyst ned til dem, der falder uden for konkurrencen og den nye ensretning. Det giver nemlig slet ingen mening at lave en stor konkurrence for alle, hvis man ikke kan udpege taberne og pege fingre af dem, som ikke deltager. Alle de forliste og skceve eksistenser. Dagpengemodtagerne, kontanthjcelpsmodtagerne, de psykisk syge, alkoholikerne, de funktionelle analfabeter, indvandrerne og originalerne. Det er mere end nogle andre dem, som samfundets 
vrede rettes imod. Hermed bliver der imidlertid ikke alene åbnet for krœnkende og aggressiv adfcrd over for de afvigende på en måde, der tilsidescetter kœrligt og omsorgsfuldt samvœr. Vi fortrœnger også alle de anderledes og skœve sider af os selv og bliver dermed mere og mere fremmedgjorte over for os selv og hinanden.

\section{Dovenskab:}

Tilsyneladende er vi blevet mere aggressive og intolerante over for mennesker, der ikke bestiller noget og nasser på os andre. Umiddelbart kunne det se ud som om dovenskab er blevet den ultimative last i en tid, der kalder på mobilisering i den globale konkurrence. Derfor er det også blevet legitimt at udstille og latterliggøre de arbejdsløse. Vreden over dovenskaben.

På den anden side er vi alle sammen blevet mere dovne i forhold til tilvœrelsen. Vi tilsidesctter mere og mere de alvorlige sider af livet og omgiver os med indholdsløs underholdning, kunstig sex, druk og tomme forbrugsgoder. Vi forestiller os hver iscer, at vi har ret til rigdom og berømmelse, og helst som noget vi kan komme let til uden anstrengelse. Reality serierne er ikke bare blevet vor tids ypperste tidsfordriv, fordi de udstiller, at virkeligheden er blevet en kynisk konkurrence, hvor man enten går videre eller bliver stemt hjem. De gør også vores egen inderste dovenskab genkendelig, fordi de påstår, at vi alle sammen har talenter til at vinde i den store konkurrence og dermed holder de fast i drømmen om, at vi hver iscer er mere end alle andre. 


\section{Om at have forspildt sit liv}

Livet er tilstrœkkeligt langt, og vi har, hvis hele vort liv anvendes godt, fået rigeligt af det til fuldførelse af de største forehavender; men hvor det flyder ud i vellevned og ligegyldighed, hvor det ikke bruges til nogen god sag, er det først i den yderste nød, at vi, uden at have set livet gå, tvinges til at indse, at det er gået ... vi modtager ikke et kort liv, men gør livet kort ... livet er langt, hvis man forstår at bruge det (Seneca, 'Om livets korthed').

En af de mest tragiske erfaringer for et menneske indtrœffer, hvis det når til en erkendelse af, at det har forspildt sit liv. At det har haft år, der er blevet levet i mørke på fortvivlelsens afgrund. År, hvor mulighederne er passeret i misbrug og flugt. År, der er blevet levet i jagten på uvœsentlige ydre mål, prestige, prœstationer og materielle vœrdier. År, der er forsvundet på grund af forkerte handlinger. År, der er blevet levet i fravœr af nœrvœer i livet.

Den erkendelse er smertefuld og forbundet med eksistentiel skyld og dårlig samvittighed. Den indtrcffer som regel, når og hvis vi når vores absolutte grcense, eller når en afgørende forandring i livet er på sit højeste.

\section{En maveplasker!}

De strukturer, mønstre og overbevisninger, vi har baseret vores liv på bryder sammen. De viser sig som illusioner, og lige pludselig er der intet. Vi står med ryggen op mod muren. Vi kan mœrke tilvœrelsens bund trykke sig imod os. Måske prøver vi at vende tilbage til vores gamle vaner og mønstre. Men på et eller andet tidspunkt går det galt igen. Ikke mindst, fordi det gamle må fastholdes krampagtigt. For nu har vi vœret berøring med dén sandhed, at vi levede på en løgn, i flugt, i usandhed, i ond tro eller bare har fortabt vores liv i kølvandet på tidligere fejltagelser.

En 34-årig mandlig advokat, Peter, måtte sygemelde sig fra sit arbejde med stress og depression og lade sig indlœgge på en psykiatrisk afdeling. Under opholdet gik det op for Peter, at han ikke ville kunne vende tilbage til sit arbejde. Peter indså, at han aldrig havde nceret et inderligt ønske om at blive advokat. Han havde i stedet altid fulgt 
familiens ønsker til sit liv. Til sidst var tomheden blevet så øredøvende, at han var blevet revet fra hinanden.

En 46-årig kvindelig psykolog, Henriette, havde i mange år levet et liv med alkohol- og hashmisbrug. Til sidst fungerede hun hverken i sit arbejde eller privatliv og blev indskrevet på et behandlingscenter. Henriette oplevede, at hun havde nået sin bund og måtte starte på ny med sit liv. Kort efter udskrivningen fra behandlingscentret blev Henriette ramt af en kraftig depression. Det gik op for hende, hvordan hun hele sit voksenliv havde forpuppet sig i sit misbrug, og at mange år og muligheder bare var forsvundet for hende på den måde.

Kirsten var 70 år, da hendes mand forlod hende til fordel for en yngre kvinde. Efter skilsmissen gik det op for Kirsten, at hun havde brugt hele sit liv på at vœre baglandskvinde for manden, der ikke kunne få børn. Kirsten havde derfor aldrig hverken fået forfulgt sit ønske om at få børn eller fået forfulgt den forfatterdrøm, som hun havde haft, siden hun som ung kvinde fik en pris som årets lyrikerdebutant. Nu var manden forsvundet, og det var både for sent for hende at få børn og forfatterkarriere.

Nœesten ti år efter sin løsladelse står livstidsfangen Palle Sørensen og kigger ud af vinduet, mens han taler med den tidligere Politibetjent Frank Bøgh, og siger: "Det var først som 71 -årig, at jeg begyndte på et normalt liv, så man kan vist godt sige, at jeg har meget at indhente. På en smuk dag som i dag, må man som 80-årig nødvendigvis erkende, at ens liv er spildt. Og véd du hvad? Det kan jeg kun takke mig selv for. Og det er egentlig ikke nogen rar tanke" (Bøgh 2007, 183).

\section{Om at vende ulykken}

It is never too late to be, what you might have been (George Eliot)

I erkendelsen af, at vi har forspildt vores liv, kan vi gå til grunde. Vi kan også flygte ind i nye illusioner, så vi mister kontakten med vores tragiske indsigt. Imidlertid har vi også en helt tredje mulighed. Nemlig at vende situationen om og bruge det fortabte til at få et rigt liv. Vi kan arbejde med at hjœlpe andre, der er i fare for at forspilde deres liv. Vi kan 
bruge vores erkendelse til at leve resten af vores liv med ekstra intensitet og ikke lade mere gå tabt.

\section{Referencer}

Bøgh, Frank (2012/2007). Palle Sørensen - Politimorder. København: People's Press

Seneca, Lucius Annaeus (2014). Livets korthed. København: Vindrose 


\section{Om at leve en dag ad gangen}

Begin at once to live, and count each separate day as a separate life

(Seneca, Moral letters to Lucilius, Letter 101)

Vi har svœrt ved at leve i nuet og leve een dag ad gangen.

Derfor oplever vi også vanskeligheder, når vi i stedet fanges af tanker omkring vores fremtid og fortid.

Vi kan vœre dybt optagede af at tœnke over de ting, som er hœndt os i vores fortid. Eller vi kan bruge krœfter på at forstå os selv og vores livssituation ud fra vores livshistorie.

Vi kan bruge oceaner af tid og krœfter på at gruble over de ting, som måske og måske ikke hcender os i vores fremtid. Vi kan have en tendens til at leve vores liv efter planer og strategier for, hvordan vi gerne vil have at vores fremtid kommer til at forløbe for os.

Ved at hcenge fast i vores fremtid eller vores fortid undgår vi at vœre til stede i vores liv, som det former sig lige nu og her. Vi bliver aldrig ncervœrende i det liv, som vi nu engang er placeret i lige nu og her. Mange af de bekymringer og megen af den lidelse, som vi oplever, skyldes, at vi ikke fokuserer på at vare til stede nu og her.

De stoiske filosoffer levede ud fra den indsigt, at vi må frigøre os fra vores fremtid og fortid og i stedet vœre til stede, der hvor vi er i livet nu og her. Ved at vœre fuldt til stede i vores liv oplever vi at vœre del af en større virkelighed, end den vores tanker kan holde os fast i gennem spekulationer over fortid og fremtid.

With the past, I have nothing to do; nor with the future. I live now (Ralph Waldo Emerson)

Livet må leves een dag ad gangen med fuldt nœrvœr og tilstedevœrelse.

Når du overgiver dig til det, der er og dermed bliver totalt nœrvœrende, ophører fortiden med at have nogen magt (Eckhart Tolle, 'Lev i nuets kraft') 
Den tyske filosof Friedrich Nietzsche fremsatte den idé, at vi må leve livet, som om vi vil have det gentaget i een uendelighed - den evige genkomst.

Bruger vi den idé som en rettesnor for vores liv, kommer vi til den erkendelse, at et liv i fortiden eller fremtiden er spild. Hvem vil have sine bekymringer for morgendagen eller sine spekulationer over fortiden gentaget i det uendelige?

\section{Referencer}

Nietzsche, Friedrich (1997). Den muntre videnskab. København: Det lille Forlag Nietzsche, Friedrich (1999). Således talte Zarathustra. København: Det lille Forlag Seneca, Lucius Annaeus (2015). Letters on Ethics. Chicago: Chicago University Press Tolle, Eckhart (2004). Lev i nuets kraft. København: Borgen 


\section{Om døden}

\section{Stoiske perspektiver på døden}

It is not death that a man should fear, but he should fear never beginning to live

Death is a release from the impressions of the senses, and from desires that make us their puppets, and from the vagaries of the mind, and from the hard service of the flesh.

Despise not death, but welcome it, for nature wills it like all else.

(Marcus Aurelius)

Stoikerne forsøgte at leve deres liv gennem en vedvarende trœning til døden. Ved at leve med et fokus på døden kunne mennesket frigøre sig fra sin afhcengighed af alt uvœsentligt og i stedet koncentrere sig om det vœsentlige i livet. Med andre ord skulle det enkelte menneske fokusere på at udvikle det, som står i dets magt, nemlig dets moralske karakterdannelse og handlingsliv, snarere end at prøve at œndre de ydre forhold, som er uden for dets magt. Vi skal ikke lade vores sjcelefred afhcenge af forhold i den ydre verden (anerkendelse, magt, penge eller prestige), som ikke står i vores magt. På den måde bliver vi fri af den ydre omverden men ikke fri for den.

Denne åbenhed for døden er i reglen en modsœtning til det at frygte døden. Vi frygter døden, fordi vi er bange for at miste det, som vi har gjort os afhœengige af. Eller fordi, der er noget, som vi endnu ikke har fået gjort.

\section{Erfaringen af døden}

Som den tyske filosof Martin Heidegger beskrev, er det døden, der giver mening og struktur til vores tilvœrelse. I reglen forsøger vi at undgå bevidstheden om døden ved at vœre optagede af alle mulige andre ting i hverdagslivet. Vi har en tendens til at lade som om, vi ikke skal dø. På den måde fylder vi alt muligt ind i vores tilvœrelse, som skal give os en oplevelse af, at vi lever evigt.

Vi kan også have en tragisk indstilling til døden. Som en uvedkommende erfaring af, at vi kan miste alt det, som vi holder af og har fyldt vores tilvœrelse ud med. Tankerne 
kredser på en negativ måde om døden, som vi frygter. Vi drømmer om døden og synes konstant, at vi bliver mindet på at vi selv skal dø. Eller at mennesker, som vi holder af, skal dø. På den måde får vi ikke greb om det liv, vi skal leve i sandhed med os selv og vores omgivelser. Når vi frygter, at vi skal dø, er det som regel fordi, vi er vores eget liv skyldige, og tankerne om døden udtrykker en dårlig samvittighed.

Vores forhold til livet kan œendre sig, når vi faktisk bliver konfronteret med vores død og ikke lœngere kan flygte fra bevidstheden om den. Den schweiziskfødte amerikansk psykiater Elisabeth Kübler-Ross beskrev, hvordan døende mennesker ofte får et œndret syn på livet. De får nu muligheden for at leve livet med større intensitet og dybde, og tiden må ikke lœengere gå til spilde.

It's only when we truly know and understand that we have a limited time on earth and that we have no way of knowing when our time is up - that we will begin to live each day to the fullest, as if it was the only one we had. (Elisabeth Kübler-Ross)

\section{Referencer}

Aurelius, Marcus (2011). Meditations. Oxford: Oxford University Press

Heidegger, Martin (2013). Varen og tid. Aarhus: Klim

Kübler-Ross, Elisabeth (2014). On Death and Dying. Scribner Book Company; Reprint edition 


\section{Kunsten at blive gammel: Gerontopœdagogisk livskunst}

Kulturens aktuelle idealisering af fornyelse, kompetenceudvikling og ungdommelighed medfører, at individets erfaring af aldringen som livsvilkår kan komme i konflikt med dets kulturelle livsvcerdier og de sociale normer. Denne konflikt udspringer af et tiltagende ubehag ved den moderne vestlige kulturs erfaring af forcldelsen som en proces med forfald, dalende kompetencer og afvikling. Konsekvensen er en stigende fortvivlelse blandt mange celdre, der enten kan vise sig som: (a) Fortvivlelse over ikke at kunne forlige sig med egen forceldelse med en forøget forekomst af angst, depression og misbrugslidelser; eller (b) fortvivlelse over at ville forblive ungdommelig med en desperat efterstrcebelse af en ny celdrenormalitet, der er forankret i ensidige sociale krav om at efterleve dekadente normer for det evigt nye og aktive. I begge tilfœlde kan fortvivlelsen forstås som udtryk for erfaringen af en eksistentiel konflikt, hvor individerne hverken er i stand til at forlige sig med deres egen dødelighed som et tragisk livsvilkår, finde en positiv mening med alderdommen eller håndtere deres frihed og tage ansvar for at forfølge deres egne ønsker. Samtidig peger denne fortvivlelse på en spirituel konflikt, hvor individualiseringen, sekulariseringen og den intensiverede trang til verdslig udødeliggørelse kan afspejle sig ved, at de celdre bliver fanget i en selvcentrering, mangler åndelig bevidsthed om at vcere en del af en selv-overskridende virkelighed og ikke er i stand til at forlige sig med tilvœrelsen som helhed.

Det er i praksis muligt at hele den fortvivlelse, som kan følge aldringserfaringen. Herunder:

(1) En sådan praksis kan finde støtte i den hellenistiske peri geros génre hos filosoffer som Cicero, Seneca og Epikur, der har som mål at omdanne mennesket til overvinde ubehaget ved alderdommen og frygten for døden? Nemlig ud fra en forståelse af filosofien som en spirituel livskunst, der er baseret på et visdomsideal og har et mål om at forme alderdommen som en forcdlende fuldendelse af livet, og dermed både som en modsctning til forcldelsen og det evigt ungdommelige.

(2) Disse indsigter kan integreres i den eksistensanalytiske terapi fra Emmy van Deurzen

og andre som en moderne filosofisk livskunst, hvis mål er at hele menneskets 
eksistentielle fortvivlelse ved at ledsage den enkelte til at forlige med sine livsvilkår og blive livsduelig, overskride sig selv og finde mening med tilvcrelsen?

(3) Disse aspekter kan anvendes til at praktisere og evaluere en gerontopadagogisk livskunst, der sœtter fokus på at hjœlpe fortvivlede œldre mennesker med en eksistentiel lcering af kunsten at fuldende livet på en livsduelig og meningsfuld måde $i$ en atilpassethed til de kulturelle livsvcerdier og sociale normer; og en spirituel omdannelse af den enkelte til at leve sin alderdom med vœrdighed og visdom for at kunne vœre bevidst til stede og åndsfrisk deltagende i verden. 


\section{Om at vœre alene, ensom, isoleret eller forladt}

\section{Alene}

Som den amerikanske psykiater Irvin Yalom pointerer, er mennesket i afgørende stunder af livet alene. Det er med andre ord et eksistentielt grundvilkår, at vi ind imellem er alene.

Helt alene er vi imidlertid aldrig. Vi er nemlig altid mindst i selskab med én person, nemlig os selv. Hvordan vi har det med at vœere alene, afhcenger derfor også af, hvordan vi har det med at vœre i vores eget selskab.

\section{Isoleret}

At vœere isoleret er en social kendsgerning. Det er i sig selv, hverken dårlig eller godt, det afhcenger af, hvad personen gerne vil.

At isolere sig kan vœre en beskyttelsesmekanisme. Det man imidlertid også vœre en selvvalgt strategi, hvorigennem man søger ind i sig selv, søger ncerhed med Gud eller andet.

\section{Ensom}

At vœre ensom er en følelsesmcessig tilstand. Her har vi en oplevelse af at vœre overladt til os selv. I reglen er det en smertelig oplevelse.

Ensomhed er et af de største problemer med samfundet i det 21 . århundrede. Vores individualisme medfører, at vi både har vanskeligt ved at vœre alene og sammen med andre. 


\section{Forladt}

At føle sig forladt er en af de svœreste menneskelige oplevelser.

At blive forladt er et menneskeligt urtraume. Fra gammel tid var det at blive forladt af flokken ensbetydende med den visse død. Det menneske, der var forladt af Gud, var ikke bare fysisk men åndeligt $d ø d t$

\section{Referencer}

Yalom, Irvin (1998). Eksistentiel psykoterapi. København: Hans Reitzels Forlag 


\section{En filosofisk udvikling af grundlaget for en livsduelighedens terapi. Revitalisering af eksistensfilosofien og stoicismen i terapeutisk henseende}

Et stigende antal mennesker har svcert ved at tackle livet i de vestlige samfund. I de senere år er antallet af danskere og andre vesterlcendinge med en psykisk lidelse vokset markant. WHO har udråbt psykiske lidelser til at vœere det største sundhedsproblem i Europa (www.who-euro.int). Omkring $25 \%$ af den vestlige befolkning forventes reelt at vœre kvalificerede til et terapeutisk tilbud (Kessler 2005).

Det udgør imidlertid et stort problem, at de dominerende livsteknologiske tilgange til terapi er utilstrœkkelige. Dels bliver tilgangene i stigende grad forankret i utopiske livsidealer om velvcere, lykke og succes. Dels bliver tilgangene i stigende grad snœvert rettet mod at forøge individets instrumentelle tilpasning til konkurrencesamfundet. Samtidig med at de gør individet centreret i sig selv som fuldt til rådighed for sin egen kontrol og rettet mod sin egen kompetence (May 201 1: xxv).

På den baggrund vil jeg afklare det filosofiske grundlag for en mere adckvat og helhedsorienteret terapeutisk tilgang, der er forankret i et begreb om livsduelighed. I den forbindelse udgør projektet en revitalisering af den eksistentielle filosofi som et tidssvarende bud på at finde menneskets plads i en problematisk verden.

Spørgsmålet er altså man kan udvikle det filosofiske grundlag for en terapeutisk tilgang, der er forankret i et begreb om livsduelighed og et mål om fuld livsudfoldelse? Her må jeg svare på 4 spørgsmål:

7. Hvordan er det muligt at udvikle en etisk tilgang til forståelse af lidelse og livsproblemer?

2. Hvordan er det muligt at udvikle en forståelse af fuld livsudfoldelse som etisk mål for en praktisk kvalificering af menneskelivet? 
3. Hvordan redegøres for et eksistentielt begreb om livsduelighed, der terapeutisk kan understøtte målet om fuld livsudfoldelse?

4. Hvordan udvikles et filosofisk grundlag for en helhedsorienteret terapeutisk tilgang, der er baseret på begrebet om livsduelighed?

\section{Baggrund}

I de senere år er antallet af danskere og andre vesterlœendinge med en psykiatrisk diagnose vokset markant, og en rœkke diagnoser er blevet identificeret som folkesygdomme (Sundhedsstyrelsen 2010; Wittchen 2011). En rœkke forskere har forsøgt at belyse denne problematik ud fra spørgsmålet om, hvorvidt og hvordan den stigende psykiatrisk diagnosticering er knyttet til en forvœrring af befolkningens psykiske tilstand, eller den snarere er knyttet til en forandring i vores forståelse af livsproblemer? (Brinkmann 2010). Nogle forskere har forsøgt at forfølge det første spor ved at demonstrere, hvordan mennesket har fået svœrere ved at håndtere livets udfordringer og efterleve lykke og -konkurrencesamfundets livsidealer (Ehrenberg 2000; Rosa 2005; Willig 2005; Petersen 2007). Andre forskere har forsøgt at følge det andet spor ved at demonstrere, hvordan 2 
den forøgede diagnosticering er udtryk for en tiltagende medikalisering af menneskelige livsproblemer og lidelse, der muligvis er kontraintentionel ved at forøge menneskets sårbarhed og mindske dets modstandsevne (Szasz 2010; Law 2007; Horwitz 2007; Furedi 2003). Mit udgangspunkt for projektet er, at begge svar peger på, at der mangler en etisk og eksistentiel snarere end medicinsk tilgang til forståelse af lidelse. En tilgang, der ikke opfatter psykisk lidelse som sygdom, men som udtryk for livsproblemer med at håndtere livet på en duelig måde i forhold til at opnå et godt liv.

Flere forskere har gjort gœeldende, at vor tids forståelse af menneskelivet er domineret af en livsteknologisk tilgang. Denne er prœget af en bestrœbelse på at optimere menneskelivetgennem brug af instrumentelle teknikker og metoder, som er baseret på målbar empirisk evidens og objektiv viden (Foucault 2010; Heidegger 2006; Rose 2009). Menneskelivet opfattes altså som en funktionel ressource, der er fuldt tilrådigt for mennesket selv og kan beherskes gennem dets egen kontrol af årsagsvirkningssammenhœnge (Jf. Heidegger 2003). Livsteknologierne orienterer sig derfor mod at forøge menneskets funktionelle livstilpasning og -kvalitet ud fra et livsideal om optimal funktionalitet og adaptivitet, der i stigende grad bevœger sig fra at vœre defineret som normalitet til at blive identificeret som lykke, succesog ve/vcre (Sørensen 2002; 2010). En rœkke forskere har påpeget, at livsteknologierne er utilstrckkelige, idet de er baseret på en reduktionistisk forståelse af mennesket. Samtidig påpeger disse forskere, at livsteknologierne bliver mere og mere knyttet til en utopisk idealisering af et selvberoende liv uden risiko og ubehag, som paradoksalt nok kan vœre med til underminere menneskets livsudfoldelse (Deurzen 2008; Harris 2010; Sørensen 2010; Jørgensen 2012). Mit udgangspunkt for projektet er, at der mangler en helhedsorienteret forståelse for en kvalificering af menneskelivet, der er baseret på et tidssvarende etisk ideal for fuld livsudfoldelse.

Flere forskere har beskrevet, hvordan det sundheds- og psyfaglige område i stigende grad bliver organiseret omkring en livsteknologisk forståelse af menneskets eksistentielle og psykiske livsproblemer og lidelser. Nemlig som diagnosticerbare psykiske sygdomme og forstyrre/ser, der begribes som udtryk for dysfunktionalitetog en dysfunktionel tilpasning til livets vilkår (Brinkmann 2010; Foucault 2005a). Det sker i sammenhœng med en œndring i den funktionelle forståelse af sundhed fra at dœekke en sncever normaltilstand med fravcr af sygdom til at dœekke en tilstand af fuldstcendig 
fysisk, socialt og psykisk velvœre (WHO 1946). Såvel WHO som en rœkke forskere er imidlertid begyndt at advokere for, at hverken den diagnostiske tankegang eller det kulturelle velvœreideal involverer en dœkkende forståelse af den udviklingsproces, hvorigennem mennesket optimerer sine muligheder for at opnå livskvalitet (WHO 2002). Derfor er begrebet livsduelighed blevet foreslået som et mere dœkkende begreb for sundhed (Austveg 1989). Samtidig er livsduelighed blevet introduceret som et nyt dannelsesideal, der kan fungere som alternativ til de sncvre kulturelle livsidealer om lykke, velvœre og succes (Schmidt 2002). I begge tilfœlde forstås livsduelighed som en evne til at tackle livet med sammenhaengskraft i en deltagende åben relation til sig selv, andre mennesker og sin omverden. Imidlertid er begrebet om livsduelighed aldrig blevet kvalificeret som grundlag for et terapeutisk perspektiv på, hvordan man kan forstå og håndtere menneskets eksistentielle lidelser. Mit udgangspunkt for projektet er, at der mangler en filosofisk redegørelse for et helhedsorienteret begreb om livsduelighed, der kan underbygge et terapeutisk mål om fuld livsudfoldelse gennem udfrielse fra lidelse.

Den internationale forskning omkring integrering af terapi med en filosofisk helhedsforståelse for menneskets liv bestrœber sig: (a) Enten på undersøge de grundløggende filosofiske principper bag psykoterapi; (b) eller på at undersøge mulighedsbetingelserne for at forstå iscr den hellenistiske og 3 
eksistentielle filosofi som en aktuelt relevant terapeutisk praksis (Deurzen 2009; Nussbaum 1994; Hadot 1995; Helting 1999; Hersch 2003; Ganeri 2010). Noget af denne forskning orienterer sig mod at skitsere filosofi som en terapi, der retter sig mod at udfri mennesket fra lidelse gennem udvikling af en evne til opnå et etisk mål om fuld livsudfoldelse (Deurzen 2009; Nussbaum 1994; Hadot 1995). Mit udgangspunkt for projektet er imidlertid, at der mangler udviklingen af et egentligt filosofisk grundlag for en tidssvarende terapeutisk tilgang, der tager afscet i begrebet om livsduelighed.

Mit projekt tager afscet i en eksistentie/ tilgang, der orienterer sig mod menneskets konkrete eksistens gennem systematisk refleksion over grundlœeggende livserfaringer. Projektet indskriver sig endvidere i en sœrlig praksisfilosofisk tradition fra isœr den hellenistiske filosofi samt den moderne eksistentielle filosofi og terapi, der har anskuet den terapeutiske håndtering af menneskelig lidelse som den primcere motivation for filosofien, hvis mål er udfoldelsen af menneskelivet (fx Epictetus 2007; Aurelius 1930; Seneca 1995; Kierkegaard 2013; Nietzsche 2005; Binswanger 1994; Boss 1979; Ure 2008; Deurzen 2012; Sørensen 2013). I forlœengelse heraf knytter projektet samtidig delvist an til de aktuelle bestrcebelser på at revitalisere iscr den antikke, tidlige kristne og eksistentielle filosofi som en praktisk livskunst, omend projektet indeholder et sœerfokus på den hellenistiske og eksistentielle tradition (Hadot 2005; Nehamas 2000; Cooper 2013; Irvine 2009; Evans 2012; Deurzen 2012; Caroll 2007; Sellars 2011). I samme forbindelse knytter projektet iscer an til Foucaults sammenstilling af en interesse for antikkens livspraksisser med en nutidig søgen efter en livscestetik og eksistensetik, der kan fungere som et alternativ til den moderne livsteknologi og -politik (Foucault 1997; 2005b; 2011 ; 2014). Modsat Foucault er ambitionen dog at afdckke en delvis kontinuitet i de historiske livserfaringer og endvidere levere en positiv formulering af grundlaget for en konstruktiv terapeutisk livspraksis.

Projektet er opdelt i 4 studier: 


\section{En filosofisk undersøgelse af en eksistensetisk tilgang til psykisk og eksistentiel lidelse}

Det første studie tager afscet i et eksistensanalytisk perspektiv, der er inspireret af Emmy van Deurzen, Michel Foucault og Martin Heidegger. Målet er at kombinere: (a) En filosofisk samtidsdiagnose af vore tids eksistentielle udfordringer; med (b) en filosofisk kritik af den konventionelle psykopatologis og -diagnostiks mulighedsbetingelser og begrcensninger som tilgang til udfordringerne; for at nå til (c) skitseringen af et tidssvarende alternativ til den moderne psykopatologi. Nemlig ved at demonstrere, hvorvidt og hvordan den hellenistiske filosofi samt den eksistentielle filosofi og terapi indeholder en rœkke konsistente trœk i erfaringen af lidelse som et etisk problem omkring eksistentiel duelighed i forhold til udfoldelse af livet. Psykisk og eksistentiel lidelse opfattes således ikke som psykopatologiske funktionsforstyrrelser og -afvigelser efter den medicinske model og psykiatriske diagnosticeringstanke. De opfattes derimod som udtryk for en problematisk livsindstilling og manglende evner til at håndtere livsproblemer.

\section{En filosofisk undersøgelse af muligheden for en tidssvarende eksistensetisk livskunst}

I andet studie benyttes det samme perspektiv til at kombinere (a) En filosofisk samtidsdiagnose af vor tids idealisering af lykke, velvcre og succes; med (b) en filosofisk kritik af livsteknologiernes mulighedsbetingelser og begrœnsninger for en kvalificering af livet gennem normalisering og bestrcebelser på lykke, velvœre og succes; for at nå til (c) 4 
skitseringen af et tidssvarende alternativ til livsteknologierne. Nemlig ved at demonstrere, hvordan den hellenistiske filosofi samt den eksistentielle filosofi og terapi indeholder en rœkke konsistente trœk i udlœgningerne af en eksistensetisk livskunst, hvis mål er at kvalificere en fuld udfoldelse af livet. Som sådan består ambitionen i at revitalisere eksistensfilosofien som en praksisfilosofisk tilgang til kvalificering af menneskelivet, der udgør et alternativ til den moderne teknologiske fornuft. Således bliver sigtet at tilvejebringe en helhedsorienteret kvalificering af det unikke menneskes fulde livsudfoldelse modsat en instrumentel beregneliggørelse og funktionalisering af menneskelivet som ressource for en normbestemt optimering. 


\section{En filosofisk redegørelse for et eksistentielt begreb om livsduelighed}

Dernœst kobles sundhedsbegrebet og det pœdagogiske dannelsesideal om livsduelighed med den forhåndenvœrende erfaringshorisont i den hellenistiske og eksistentielle tradition for at definere et eksistentielt begreb om livsduelighed. Ambitionen er, at der på tvœrs af de forskellige teoretiske og historiske positioner kan indfanges en konsistent erfaring af, hvordan den fulde udfoldelse af livet forudscetter udviklingen af en scrlig duelighed til at leve livet. I den forbindelse er målet at skitsere et begreb om livsduelighed, der netop ikke dœkker en funktionel kompetence eller teknik. En kompetence til livstilpasning, som det selvberoende menneske kan indlcere eller optimere instrumentelt som det f.eks. gør sig gœldende i nyere livsteknologiske teorier om mestring, self-efficacy, coping og resiliens (fx Southwick 2012; Lazarus 1984; Bandura 1997). Begrebet må derimod for det første indfange en eksistentiel duelighed for det enkelte menneske til at håndtere sit eget liv i en åben vœren-i-verden. En duelighed, der for det andet udvikles igennem en eksistentiel dannelse, og som er udtryk for en eksistentiel sundhed i forhold til at udfolde livets muligheder i frihed (jf. Colaizzi 1998; Gadamer 2010; Austveg 1989; Schmidt 2002)

\section{Systematisering af det filosofiske grundlag for en livsduelighedens terapi}

Endelig indarbejdes resultaterne fra de tre første studier i en diskussion af de aktuelle bestrcebelser på at forene terapi og en filosofisk helhedsforståelse af menneskelivet. Ambitionen er formuleringen af et filosofisk grundlag for en etisk-terapeutisk livskunst, der kan tilvejebringe en udfrielse fra lidelse og udfoldelse af livet gennem en kvalificering af livsdueligheden.

Projektet giver original viden af stor aktuel relevans omkring anvendt etik og praksisfilosofi og bidrager visioncert til den danske og internationale forskning $i$ forståelsen af psykiske lidelser og udviklingen af eksistentiel filosofi og filosofisk terapi. 


\section{Litteratur}

Aurelius, M. (1930). Meditations, US: Harvard University Press

Austveg, B. (1989). Helsearbeid og innvandrere: mangfold, sunnhet og sykdom, Oslo: Tano

Bandura, A. (1997). Self-efficacy. The exercise of control, US: Worth 5 
Binswanger, L. (1994). Ausgewählte werke 7-4, Heidelberg: Asanger

Boss, M. (1979). Existential Foundations of Medicine and Psychology, NY: Jason Arenson Brinkmann, S. (red.)(2010). Det diagnosticerede liv, Århus: Klim

Caroll, J. (2007). The Existential Jesus, Berkeley: Counterpoint

Colaizzi, P. (1998). Eksistentiel løering, I: M. Hermansen (red) Lceringens horisont, Aarhus: Klim

Cooper, J. (2013). Pursuits of wisdom, Princeton: Princeton University Press

Deurzen, E. (2008). Psychotherapy and the Quest for Happiness, London: Sage Publications Ltd.

Deurzen, E. (2009). Everyday mysteries, London: Routledge

Deurzen, E. (2012). Existential counselling and psychotherapy in practice, London: Sage Ehrenberg, A. (2000). Det udmattede se/v. Depression og samfund, Kbh.: Informations Forlag

Epictetus (2007). Art of living, US: HarperOne

Evans, J. (2012). Philosophy for life, London: Rider

Foucault, M. (1997). Ethics. The essential works 7, London: Penguin

Foucault, M. (2005a). Sindssygdom og patologi, Kbh.: Hans Reitzels Forlag

Foucault, M. (2005b). The Hermeneutics of the Subject, NY: Palgrave Macmillan

Foucault, M. (2010). The Birth of Biopolitics, NY: Palgrave Macmillan

Foucault M. (2011). The Government of the Self and Others 1-2, NY: Palgrave Macmillan

Foucault, M. (2014). On the Government of the Living, NY: Palgrave Macmillan 
Furedi, F. (2003). Therapy Culture: Cultivating Vulnerability in an Uncertain Age, London: Routledge

Gadamer, H-G. (2010). Über die Verborgenheit der Gesundheit, Frankfurt: Suhrkamp

Ganeri, J. \& C. Carlisle (2010). Philosophy as Therapeia, Cambridge: Cambridge University Press

Hadot, P. (1995). Philosophy as a way of life, UK: Blackwell

Harris, R. (2008). The Happiness Trap: How to Stop Struggling and Start Living, US: Trumpeter

Heidegger, M. (2003). Holzwege, Frankfurt a.M.: Vittorio Klostermann

Heidegger, M. (2006). Zollikoner Seminare, Frankfurt a.M.: Vittorio Klostermann

Helting, H. (1999). Einführung in die philosophischen Dimensionen der psychotherapeutischen Daseinsanalyse, Aacen: Shaker Verlag

Hersch, E. (2003). From Philosophy to Psychotherapy, Toronto: University of Toronto Press Horwitz, A. \& Wakefield, J. (2007). The Loss of Sadness, Oxford: Oxford University Press

Irvine, W. (2009). A guide to the good life. The ancient art of stoic joy, Oxford: Oxford University Press

Jørgensen, C. R. (2012). Danmark på briksen, Kbh.: Hans Reitzels Forlag

Kessler, R. (2005) Lifetime prevalence and age-of-onset distributions of DSM-IV in the National Comorbidity Survey Replication, Arc. General Psychiatry, 62(6), 593-602

Kierkegaard, S. (2013). Søren Kierkegaards samlede skrifter, Kbh.: Gad

Lazarus, R. (1984). Stress, appraisal and coping, US: Springer

Law, C. (2007). Shyness, New Haven \& London: Yale University Press 
May, R. (201 1). Foreword, In Norcross (ed.) History of psychotherapy, Washington DC: APA

Nehamas, A. (2000). Art of living, US: University of California Press

Nietzsche, F (2005). Sämtliche werke, D: DeGruyer

Petersen, A. (2007). Depression - vor tidsalders vrangside, Örebro: Öbebro Studies in Sociology

Rosa, H. (2005). Beschleunigung, Frankfurt: Suhrkamp

Rose, N. (2009). Livets politik - biomedicin, magt og subjektivitet i det 21. århundrede, Kbh.: DPF

Schimmel, S. (1997). The Seven Deadly Sins, Oxford: Oxford University Press 


\section{Udfrielse fra lidelse - Livsduelighed som mål for en filosofisk terapeutik}

Udgangspunktet for projektet er, at eksistentiel lidelse er i vœkst i vores samfund på trods af et grundløeggende kulturelt ideal om at opnå lykke, velvœere og succes. Formålet med projektet er at undersøge udvikle en filosofisk lœere om forståelse og håndtering af eksistentiel lidelse, der tilbyder et konstruktivt svar på vor tids livsproblemer ved at vœre forankret i et eksistensetisk begreb om livsduelighed.

Livsduelighed har igennem lœengere tid varet studieobjekt inden for biologien samt et praksismål inden for dansk uddannelse og padagogik i en tradition fra N. F. S. Grundtvig og K. E. Løgstrup. At orientere sig mod og studere livsduelighed er således ikke nyt. Det forskningsmœssige nye ved projektet ligger derimod i at udarbejde et filosofisk studie af livsduelighed, der er specifikt motiveret af et terapeutisk spørgsmål om udfrielse fra lidelse.

\section{Litteraturen}

I vores samtid domineres forståelsen af eksistentielle lidelser af livsteknologier, der definerer lidelserne som diagnosticerbare psykiske sygdomme og forstyrrelser, der forstås som udtryk for en dysfunktionel tilpasning til livets vilkår (Brinkman 2010). Det sker ud fra en bestrcbelse på at optimere menneskelivet gennem brug af instrumentelle teknikker og metoder, der er baseret på målbar empirisk evidens og objektiv viden (Sørensen 2002; 2012). Flere forskere har gjort gœldende, at livsteknologierne må forstås som led i en generel livspolitik og biomagt, der gennemsyrer det sociale og kulturelle liv med henblik på at fremme befolkningens kvantitative levetid og livskvalitet (Foucault 2010; Campbell 2011). Livsteknologierne orienterer sig derfor mod at forøge menneskets funktionelle tilpasning til livsvilkårene ud fra det ideal om livskvalitet, der i stigende grad bestemmes som individuel lykke, velvare og succes. Alligevel meldes der om en øget forekomst af lidelser, der inden for en livsteknologisk forståelsesramme bl.a. kategoriseres som depression og stress (Nielsen 2007; WHO 2003). 
At livsteknologierne orienterer sig mod forøgelse af lykke, velvœre og succes ses bl.a. i udbredelsen af de humane bio- og neuroteknologier samt life-coaching, den kognitive adfœrdsterapi, copingpsykologien og mestringspœdagogikken samt den positive psykologi og pœedagogik. Den grundløggende problematik er, at disse tilgange ikke er vidtrakkende nok til håndteringen af menneskets eksistentielle lidelser. De individualiserer lidelsen, og de reducerer den til en funktionel forstyrrelse, der må forstås gennem teknologiske begreber og tilvœrelsestolkninger. Dermed umuliggør de ikke alene blikket for lidelsens sociale og kulturelle baggrunde men også for dens eksistentielle dimensioner.

I en eksistentiel forståelsesramme er vœksten af psykiske sygdomme og forstyrrelser udtryk for, at den eksistentielle oplevelse af ubehag, meningsløshed og mislykkethed i livet opretholdes eller vokser blandt mange. Det peger på, at flere har svcert ved at håndtere livets udfordringer og orientere eksistensen, og flere forskere har påpeget, at det hcenger sammen med den kulturelle og sociale idealisering af et selvcentreret liv uden risiko og ubehag (Deurzen 2008; Harris 2010; Sørensen 2010; Jørgensen 2012). Paradoksalt nok er det således måden, hvorpå vi forsøger at tilpasse os de kulturelle og sociale normer om individualitet og efterstrceber lykke, velvœre og succes, der netop er med til at skabe rådvildhed og rodløshed og frembringe eksistentiel lidelse.

\section{Problemformulering, idé og målscetning}

På denne baggrund er projektets problemformulering:

Hvordan kan man udvikle en tilgang til udfrielse af mennesket fra eksistentiel lidelse, der er funderet i idéen om livsduelighed som et helhedsorienteret livsideal, som ikke leder mennesket mod en funktionel livstilpasning men mod at leve et meningsfyldt liv i samspil med omgivelserne?

Projektet første tese er, at løsningen af denne problemstilling forudscetter en kobling af en filosofisk forståelse for menneskets hele eksistens med en terapeutisk tilgang til udfrielse fra menneskelig lidelse. Aktuelt er den relevante internationale forskning omkring integrering af filosofi og terapi opdelt i dels en terapeutisk fløj, der bestrceber sig på at give psykoterapien en egentlig praksisfilosofisk form, men denne fløj har endnu ikke formået at omdanne terapien til en konsistent filosofisk løere om forståelse og 
håndtering af menneskelig lidelse (fx Helting 1999; Deurzen 2009). Dels en filosofisk fløj, der isœr har forsøgt at revitalisere den hellenistiske filosofis terapeutiske potentiale, men denne fløj har endnu ikke formået at omdanne filosofien til en anvendelig terapi ( $f x$ Nussbaum 1994; Hadot 1995). Det første mål med projektet er derfor at integrere: (1) Den terapeutiske fløjs praktiske tilgang til håndtering af eksistentiel lidelse som et fœnomen, der må begribes i etiske kategorier som problemer med livet og dets mening, og som udspringer af dilemmaer og paradokser i menneskets livsvilkår og livsindstilling; (2) og den filosofiske fløjs forståelse af filosofien som en fornuftsbaseret livspraksis, hvis opgave ikke er den rene erkendelse men derimod at finde menneskets plads i en problematisk verden ved at orientere det mod fuld og engageret livsudfoldelse gennem udvikling af livsduelighed.

Ifølge projektets anden tese forudscetter problemets løsning en afklaring af det helhedsorienterede livsideal og midlerne til at nå det. Forskere har bragt det pœdagogiske begreb om livsduelighed i spil som et relevant alternativ til de sncevre idealer om lykke, velvœre og succes, men idéen er ikke blevet givet substans i en terapeutisk ramme (Schmidt 2007). De ncevnte fløje indeholder forståelser af en praktisk livsfornuft, der involverer pœdagogisk erhvervelse af kundskaber og fœrdigheder, som er baseret på mangfoldigheden og dybden af menneskelige livserfaringer. Disse forståelser er ikke dog integreret i et sammenhœngende koncept om udfrielse fra lidelse gennem lœring og dannelse af livsduelighed. Det andet mål med projektet er derfor, at fusionere: (1) Den terapeutiske fløjs idé om guidet lœering af dispositionen til at tackle livets udfordringer og påvirkninger i meningsfuld og autentisk åbenhed for én selv, andre mennesker og omverden; (2) og den filosofiske fløjs idé om orientering af mennesket mod fuld udfoldelse af et rigt, alsidigt og meningsfuldt liv i et selvoverskridende samspil med omgivelserne gennem fascilitering af en refleksiv livsvisdom, der udgør et dannelsesideal og ledes af en viis mentor.

\section{Forskningsspørgsmål}

På den baggrund kan min problemformulering og tese undersøges gennem følgende 3 forskningsspørgsmål, der samtidig udpeger på 3 forskningsmål:

1. Hvordan udvikler man en etisk forståelse af menneskets eksistentielle lidelser? 
2. Hvordan fremstiller man et bredt og helhedsorienteret begreb om livsduelighed?

3. Hvordan udvikler en filosofisk terapeutik, der er motiveret at spørgsmålet om menneskelig lidelse og orienteret mod livsduelighed?

\section{Teoretisk ramme og analysestrategi}

Projektet tager afsœt i en eksistensanalytisk tilgang, der udgør en filosofisk modifikation af den psykoanalytiske terapi, som er baseret på eksistentielle, hermeneutiske og fœnomenologiske principper (Deurzen 2009). Tilgangen omfatter en analyse af den menneskelige tilvœrelse med fokus på den måde, hvorpå mennesket giver mening og retning til sin eksistens i konfrontationen med livets vilkår. Projektet tager isœr afsct i den aktuelle britiske eksistensanalyse, der hovedsageligt er udviklet af Emmy van Deurzen som en lœeringsorienteret og terapeutisk praksisfilosofi med et fokus på menneskelig erfaring. Samtidig udlœgges eksistensanalysen som en etisk livskunst, der er orienteret mod at udvikle evnen til at tackle livets udfordringer i relationel åbenhed, og som dels anser sig som en moderne variant af den praksisfilosofiske tradition fra den hellenistiske filosofi, og dels som funderet i den moderne eksistentielle tradition inden for filosofi og terapi. Det er påpegningen af dette dobbelte slœgtskab som projektet vil eksplicitere i udviklingen af en egentlig terapeutik.

Indledningsvist vil projektet tage udgangspunkt i en eksistensanalytisk samtidsdiagnose af dilemmaer og paradokser i de måder, som det aktuelle menneske forsøger at orientere sin eksistens og håndtere livets udfordringer på ved at rette et kritisk fokus mod faglitteratur omkring udbredelse af lidelse i vor tids samfund og livsteknologisk faglitteratur omkring fremme af lykke, velvœre og succes (fx Seligman 2011; Harrold 2001; Pearl 2012).

På den baggrund vil projektet undersøge muligheden for et fremstille en filosofisk terapeutik, der kan udgøre grundlaget for et relevant alternativ til de moderne livsteknologier ved at identificere en terapeutisk og pcedagogisk livspraksis, der er orienteret mod livsduelighed. Det vil ske ud fra en eksistentiel analyse af forskellige filosofiske erfaringsdannelser omkring forståelse og udvikling af livsduelighed, der er motiveret af spørgsmålet omkring menneskelig lidelse. I den forbindelse fokuseres der specifikt på erfaringsdannelser inden for to dimensioner med henblik på at udfolde den 
eksistentielle analyse af livsduelighed og lidelse gennem en tematisk fokusering på de 3 kategorier livspraksis, terapi og padagogik:

- For det første i den stoiske og epikurciske filosofi, hvor filosofien forstås som en praktisk og terapeutisk livsform, hvis mål er en dybdegående forandring af mennesket.

- For det andet i den eksistentielle, fcenomenologiske og hermeneutiske filosofi og terapi, som lader den praktiske forståelse og håndtering af menneskets konkrete eksistens fremtrcede som et filosofisk anliggende.

Herigennem fremdrages en rœkke praksisfilosofiske principper, som syntetiseres til en sammenhœengende eksistensanalytisk terapeutik, der kan fungere som grundlag for en praktisk terapi.

\section{Hvilken ny viden ventes at blive tilført?}

Projektet vil overordnet set tilføre ny viden om, hvordan eksistentiel lidelse kan forstås og håndteres ud fra en etisk forståelsesramme i henhold til et begreb om livsduelighed, der både kan fungere som et dannelsesideal og sundhedsmål i forhold til at give menneske et kvalificeret forhold til livet. Dette vil både have teoretisk og praktisk relevans for de pœdagogiske, sundhedsmœssige og terapeutiske fagområder, hvor der i dag er et stort behov for at kvalificere fokus gennem mere helhedsorienterede og dybdegående visioner i forhold til menneskets livsudfordringer. Herunder vil projektet give et grundlag for udvikling af konkrete terapeutiske redskaber, der er forankret i en konsistent filosofisk forståelse af menneskets eksistensvilkår.

Projektet vil specifikt tilføre viden om, hvordan filosofien kan videreudvikles til en eksistentiel praksis, der også sociale implikationer, idet den søger at rekonfigurere menneskets måde at agere på i forhold til sine sociale og kulturelle livsbetingelser ved at orientere det fra individuel tilpasning til et åbent samspil.

\section{Litteraturliste}

Brinkman, Svend (red.) (2010)- Det diagnosticerede liv. Århus: Klim 
Deurzen, Emmy van (2008). Psychotherapy and the Quest for Happiness. London: Sage Publications Ltd.

Deurzen, Emmy van (2009). Everyday mysteries - existential perspectives in psychotherapy. London: Routledge

Foucault, Michel (2010). The Birth of Biopolitics. NY: Palgrave Macmillan

Hadot, Pierre (1995). Philosophy as a Way of Life: Spiritual Exercises from Socrates to Foucault. Padstow: Wiley Blackwell

Harris, Russ (2008). The Happiness Trap: How to Stop Struggling and Start Living, US: Trumpeter

Harrold, Fiona (2001). Be Your Own Life Coach: How to Take Control of Your Life and Achieve Your Wildest Dreams, Hodder Paberbacks

Helting, Holger (1999). Einführung in die philosophischen Dimensionen der psychotherapeutischen Daseinsanalyse, Aachen: Shaker Verlag

Jørgensen, Carsten René (2012). Danmark på briksen. Et psykologisk perspektiv på Danmark og danskerne i det senmoderne, Kbh.: Hans Reitzels Forlag

Nielsen, N. \& T. Kristensen (2007). Stress i Danmark - Hvad ved vi? Kbh.: Sundhedsstyrelsen

Nussbaum, Martha (1994). Therapy of Desire - Theory and Practice in Hellenistic Ethics, Princeton: Princeton University Press

Pearl, Susie (2012). Instructions for Happiness and Success: A step-by-step mind manual for creating the life you choose (100\% Guaranteed), Quadrille

Schmidt, Lars-Henrik \& Claus Holm (2007). Fra velfœrdsstat til velvcerestat, I. Dagbladet Information. 27. August

Seligman, Martin (2011). Flourish: A New Understanding of Happiness and Well-Being and How To Achieve Them, NBP

Sørensen, Anders Drœby (2002). Den biologiske psykiatris renœssance og det antidepressive menneske, l: Slagmark - Tidsskrift for ldéhistorie: 35

Sørensen, Anders Drœby (2010). The Paradox of Modern Suffering, I: Tidsskrift for Forskning i sundhed og samfund. 13 
Sørensen, Anders Drœby (2012). Integrationen af psykoterapi og lœringsmodeller i et praksisudviklingsperspektiv, I: Slagmark - Tidsskrift for ldéhistorie: 64

WHO (2003). Mental Health Context, Geneva: World Health Organization 